\title{
Characterization and selection of ornamental pineapple hybrids with emphasis on sinuous stems and black fruits ${ }^{1}$
}

\author{
Orjana Santos Lima ${ }^{2}$, Everton Hilo de Souza ${ }^{2}$, \\ Lucas Ezequiel da Costa Dias ${ }^{2}$, Cintia Paula Feitosa Souza ${ }^{2}$, Fernanda Vidigal Duarte Souza ${ }^{3}$
}

\begin{abstract}
Ornamental fruit plants have a good potential for the development of innovative products for the floriculture segment, and the ornamental pineapple has attracted a strong interest in this segment. This study aimed at characterizing and selecting new ornamental pineapple hybrids for the production of cut flowers, with emphasis on stem sinuosity and a nearly black color for fruits. Twenty-three morphological descriptors were studied in 26 hybrids developed from six progenies, involving different botanical varieties. These descriptors are among those published by the Brazilian Ministry of Agriculture for protection of cultivars. The 26 hybrids evaluated fitted in different use categories: 5 for the production of cut flowers, 11 as potted plants, 6 for the production of mini fruits, 6 for foliage and 26 for landscaping. One hybrid with sinuous stems to produce cut flowers and 12 hybrids bearing nearly black fruits for ornamental use were selected as a novelty for the flower market.
\end{abstract}

KEYWORDS: Ananas comosus; cut flower; ornamental fruit plants; floriculture.

\section{INTRODUCTION}

The market for flowers and ornamental plants is dynamic, and there is a constant search for novelty. Tropical flowering plants have been gaining increasing space in this segment, both in Brazil and internationally, due not only to the exuberance and diversity of their flowers, but also because of their uniqueness and durability.

In this context, fruits traditionally cultivated for nutritional purposes are an alternative for ornamental use and can offer a wide range of products, including varieties for potted plants, living fences and landscaping, as well as for the production

\section{RESUMO}

Caracterização e seleção de híbridos de abacaxizeiro ornamental com ênfase em hastes sinuosas e frutos negros

A fruticultura ornamental tem grande potencial na geração de produtos inovadores para o segmento de floricultura, e o abacaxi ornamental vem se consolidando nesse segmento. Objetivou-se caracterizar e selecionar novos híbridos de abacaxizeiro ornamental para uso como flor de corte, com ênfase na sinuosidade da haste e na coloração quase negra dos frutos. Foram aplicados 23 descritores morfológicos em 26 híbridos provenientes de seis progênies, envolvendo diferentes variedades botânicas. Os descritores morfológicos utilizados foram publicados pelo Ministério da Agricultura, Pecuária e Abastecimento para a proteção de cultivares. Os 26 híbridos avaliados se enquadraram em diferentes categorias de uso: 5 para corte, 11 para vaso, 6 para minifrutos, 6 para folhagem e 26 para paisagismo. Um híbrido com hastes sinuosas para uso como flor de corte e 12 híbridos com frutos quase negros para uso ornamental foram selecionados como novidade para o mercado de flores.

PALAVRAS-CHAVE: Ananas comosus; flor de corte; fruticultura ornamental; floricultura.

of cut flowers and mini fruits (Souza et al. 2012a and 2014).

The use of fruit-bearing plants for ornamental purposes in Brazil is still incipient, being mainly restricted to private gardens. However, efforts have been made in recent years to change this situation, with the emergence of genetic breeding programs aiming to develop ornamental varieties of fruit species, such as pineapple (Souza et al. 2009, 2012a and 2014, Costa Junior et al. 2016), banana (SantosSerejo et al. 2007 and 2012, Souza et al. 2012b) and citrus (Santos et al. 2015 and 2016). Many of these efforts have been carried out by the Embrapa Mandioca e Fruticultura. This research follows the

1. Manuscript received in Mar./2017 and accepted for publication in Jun./2017 (http://dx.doi.org/10.1590/1983-40632016v4746163).

2. Universidade Federal do Recôncavo da Bahia, Cruz das Almas, BA, Brazil.E-mails: orjanasl@yahoo.com.br, hilosouza@gmail.com, lucas4sete@hotmail.com, cintiapaula_2006@hotmail.com.

3. Empresa Brasileira de Pesquisa Agropecuária (Embrapa Mandioca e Fruticultura), Cruz das Almas, BA, Brazil. E-mail: fernanda.souza@embrapa.br. 
footsteps of European and Asian countries, where investments have been made for the development of hybrids and improvement of these same three species (Häkkinen \& Sharrock 2001, Del Bosco 2003, Stokes 2004, Sanewski 2009).

Cross-breeding to develop superior ornamental pineapple genotypes began in 2003, and various hybrids have been selected for the production of cut flowers, mini fruits and ornamental foliage, as well as for use as potted plants and in landscaping. Two hybrids (BRS Anauê and BRS Boyrá) were commercially launched in 2016, after agronomic validation, and are now sold in the market as ornamental plants, mainly in Europe. This work has involved the prospection of ornamental genotypes in germplasm banks and directed hybridization, in search of new varieties with traits of interest in the flower and ornamental plant market, in various niches. Among these are the traditional ones of cut flowers, potted plants and landscaping, as well as the development of a totally new product line of ornamental plants bearing mini fruits (Souza et al. 2009, 2012a, 2012b and 2014, Santos et al. 2015 and 2016). A new selection process to develop pineapple genotypes bearing nearly black fruits and/or sinuous stems may open new market perspectives in Brazil and abroad.

Among the characteristics traditionally demanded in the European market are straight stems, with average length of $40 \mathrm{~cm}$ and no deformation (Souza et al. 2014). However, recent observations and surveys at international trade fairs and other events indicate that there is a good acceptance and even a preference among professionals (floral designers and landscapers), as well as consumers, for curvy stems. Sinuous stems lend a sense of movement to floral arrangements, a feature that is important to these professionals for purposes of artistic differentiation (Souza et al. 2015). Another trait that can be an attractive novelty is the fruit coloration. In previous selections, the aim has been to achieve pink or red coloration. However, fruits with dark blue/purple or nearly black color have stood out in some progenies maintained in the field (Lima et al. 2015).

Therefore, this study aimed at selecting pineapple plants with sinuous stems and/or black fruits as candidates for novel products in the floriculture market, both domestic and foreign. These new genetic materials present broad aptitude for use as potted plants or for landscaping, as well as to produce cut flowers.

\section{MATERIAL AND METHODS}

The study was carried out in Cruz das Almas, Bahia state, Brazil, where the climate, according to the Köppen scale, ranges from Am to Aw. The crop treatment and phytotechnical management of the progenies followed recommendations by Cunha et al. (1999).

Twenty-six hybrids, still in the sexual cycle, were obtained from 6 progenies involving crosses between 10 accessions, from the pineapple active germplasm bank of the Embrapa Mandioca e Fruticultura, of four different botanical varieties: Ananas comosus var. ananassoides, $A$. comosus var. erectifolius, A. comosus var. comosus and $A$. comosus var. bracteatus. Twentythree morphological descriptors were applied, being 11 quantitative and 12 qualitative, as published by the Brazilian Ministry of Agriculture, according to the standards and indications of the National Service to Protect Cultivars applicable to ornamental pineapple varieties (Brasil 2013).

The 11 quantitative descriptors were: plant height $(\mathrm{cm})$; leaf " $\mathrm{D}$ " length $(\mathrm{cm})$; leaf " $\mathrm{D}$ " width (cm); peduncle length after closure of the last flower (cm); peduncle diameter after closure of the last flower $(\mathrm{cm})$; number of peduncle curves; syncarp length after closure of the last flower $(\mathrm{cm})$; syncarp diameter after closure of the last flower $(\mathrm{cm})$; crown length after closure of the last flower $(\mathrm{cm})$; crown diameter after closure of the last flower $(\mathrm{cm})$; and crown/syncarp ratio. In turn, the following descriptors were applied to the qualitative traits: plant habit; presence/absence of leaf variegation; distribution of leaf variegation; presence/absence of anthocyanin in leaves; peduncle shape; syncarp shape; syncarp color; bract apex shape; bract shape at crown base; overlap of bracts in relation to fruitlet; number of crown colors; and crown apex shape. The colors were identified using the table of the Royal Horticulture Society Colour Chart, adopted for protection of ornamental plants by the International Union for the Protection of New Varieties of Plants.

After these evaluations, the hybrids were grouped in use categories and selected according to the method described by Souza et al. (2012a):

a) Cut flowers: crown/syncarp ratio near 1 , syncarp length smaller than $8.00 \mathrm{~cm}$, syncarp diameter smaller than $6.00 \mathrm{~cm}$, peduncle length greater than $40.00 \mathrm{~cm}$, peduncle diameter smaller than $1.50 \mathrm{~cm}$ and crown length smaller than $7.00 \mathrm{~cm}$; 
b) Cut flowers with sinuous peduncle: syncarp length smaller than $8.00 \mathrm{~cm}$, syncarp diameter smaller than $6.00 \mathrm{~cm}$, peduncle length greater than $50.00 \mathrm{~cm}$ considering sinuosity/number of curves, peduncle diameter smaller than $1.50 \mathrm{~cm}$ and crown length smaller than $7.00 \mathrm{~cm}$;

c) Potted plants: plant height smaller than $65.00 \mathrm{~cm}$, crown diameter smaller than $80.00 \mathrm{~cm}$, leaf length smaller than $60.00 \mathrm{~cm}$, crown/syncarp ratio near 1, syncarp length smaller than $5.00 \mathrm{~cm}$, syncarp diameter smaller than $3.00 \mathrm{~cm}$, crown length smaller than $5.00 \mathrm{~cm}$, peduncle length smaller than $30.00 \mathrm{~cm}$ and absence of thorns;

d) Landscaping: a broad category that may include any use category, except (in the case of pineapple) for genotypes that produce concealed fruits (inserted in the foliar rosette and covered by the leaves);

e) Mini fruits: syncarp length smaller than $5.00 \mathrm{~cm}$, crown/syncarp ratio near 1 and crown length smaller than $4.50 \mathrm{~cm}$;

f) Foliage: leaf length greater than $80.00 \mathrm{~cm}$, leaf width greater than $4.00 \mathrm{~cm}$, intense color and absence of thorns.

The new trait evaluated (stem sinuosity) is not found in any of the categories described by Souza et al. (2012a), but was included as a new product characteristic in the cut flower category, requiring its own description for selection.

The following descriptive parameters were calculated, using the SAS statistical software (SAS Institute 2010): average, minimum and maximum values and coefficient of variation. The qualitative and quantitative data were used for analysis of genetic distance, based on the Gower (1971) algorithm. The hierarchical groupings were obtained by the Unweighted Pair Group Method with Arithmetic Mean (UPGMA), employing the mean Euclidian distance between the clones and parents. The groupings were represented in a dendrogram and validated by the cophenetic correlation coefficient (r) (Sokal \& Rohlf 1962).

\section{RESULTS AND DISCUSSION}

A good diversity of colors and morphologies was observed, confirming the great variability between the hybrids and the crosses evaluated. The average, minimum and maximum values, standard deviation and coefficient of variation $(\mathrm{CV} \%)$ for all the quantitative traits of the 26 hybrids evaluated in the different crosses are presented in Table 1.

The descriptive statistics demonstrated a wide variation between progenies for all the traits evaluated. The smallest plants were obtained from the ERE x ANA cross, while the largest plants were obtained from the ERE $x$ BRA1 and BRA x ERE crosses (Tables 1 to 3). Plant height is an important characteristic, mainly in the selection of varieties for use as potted plants, since tall plants are not suitable in this category (Souza et al. 2012a). Potted plants need to be compact, as tall plants require very complicated adjustments in their production system to make their size compact.

Peduncle length was another trait that presented a wide variation, with average values from $26 \mathrm{~cm}$ for the ERE x ANA cross to $79 \mathrm{~cm}$ for the ANA $x$ (ERE x ANA) triple cross (Tables 1 to 3), where sinuous stem was selected. These plants presented peduncle with one to three curves, indicating a lack of standardization for this trait.

The peduncle diameter varied from $0.75 \mathrm{~cm}$ to $1.85 \mathrm{~cm}$ among the hybrids evaluated. This trait is directly related to the final weight of the plant, which is relevant for transportation, particularly in the case of exportation. Very thick peduncles weigh more, making shipment more expensive. Small peduncle length and diameter are also more suitable for potted plants.

The syncarp and crown measurements were also highly variable among the crosses, influencing the crown/syncarp ratio. Characteristics related to the fruit (syncarp + crown) are important to determine a good balance between them, with a crown/syncarp ratio near 1 being considered ideal by Souza et al. (2012a). Crowns that are much larger than the syncarp (ratio higher than 1) may cause the stem to break at the point of joining the peduncle, and very small crowns can compromise the esthetics of the fruit. In this study, the hybrids from the triple cross ANA x (ERE x ANA) presented the lowest crown/ syncarp ratio, with an average of 0.65 .

For selection of potted plants, the hybrids from the ERE x ANA cross had the best values, according to the description by Souza et al. (2012a). This cross had the smallest plant height $(52.25 \mathrm{~cm})$, leaf length $(49.63 \mathrm{~cm})$ and peduncle length $(26.00 \mathrm{~cm})$, meaning they are small and compact, with better potential to adapt to a production system in pots (Tables 1 to 3). Nevertheless, these values can still be 
considered high for potted plants sold at nurseries. However, these hybrids were selected as they can be modified by the production system to better fit as potted plants.

The potted plants market has been growing faster than that for cut flowers. Consumers have a perception of a better cost $\mathrm{x}$ benefit relation due to the longevity of living plants x cut flowers (Sebrae 2015).
The genetic dissimilarity dendrogram among the 26 pineapple hybrids, considering the 23 descriptors (qualitative and quantitative) are presented in Figure 1. This figure also shows how the hybrids were classified in the different use categories recommended by Souza et al. (2012a).

The cophenetic correlation coefficient of the dendrogram $(r=0.77, p<0.0001,10,000$

Table 1. Morphological descriptors of pineapple plants grouped by progenies.

\begin{tabular}{|c|c|c|c|c|c|c|c|c|c|c|c|}
\hline & PLH & LLD & LWD & PEL & PED & NPC & SYL & SYD & CRL & CRD & CSR \\
\hline \multicolumn{12}{|c|}{ ANA x (ERE x ANA) } \\
\hline Average & 71.00 & 69.00 & 2.70 & 79.00 & 1.20 & 2.16 & 7.10 & 5.00 & 4.60 & 2.80 & 0.65 \\
\hline Minimum & 63.00 & 67.70 & 2.40 & 74.80 & 1.10 & 1.00 & 6.20 & 4.90 & 3.30 & 2.50 & 0.53 \\
\hline Maximum & 79.00 & 70.30 & 3.00 & 83.20 & 1.30 & 3.00 & 8.00 & 5.10 & 5.30 & 3.10 & 0.66 \\
\hline $\mathrm{SD}$ & 11.31 & 1.83 & 0.42 & 5.94 & 0.14 & 0.75 & 1.27 & 0.14 & 1.41 & 0.42 & 0.12 \\
\hline CV (\%) & 15.93 & 2.65 & 15.56 & 7.52 & 11.67 & 34.72 & 17.89 & 2.80 & 30.65 & 15.00 & 18.52 \\
\hline \multicolumn{12}{|c|}{$\mathrm{COM} \times \mathrm{COM}$} \\
\hline Average & 55.00 & 47.00 & 2.25 & 32.50 & 1.25 & - & 5.85 & 5.85 & 5.65 & 4.40 & 0.97 \\
\hline Minimum & 54.00 & 43.00 & 2.00 & 28.00 & 1.20 & - & 4.80 & 4.90 & 3.50 & 3.00 & 0.73 \\
\hline Maximum & 56.00 & 51.00 & 2.50 & 36.00 & 1.30 & - & 6.90 & 6.80 & 7.80 & 5.80 & 1.13 \\
\hline $\mathrm{SD}$ & 1.41 & 5.66 & 0.35 & 6.01 & 0.07 & - & 1.48 & 1.34 & 3.04 & 1.98 & 0.22 \\
\hline CV (\%) & 2.56 & 12.04 & 15.56 & 18.49 & 5.60 & - & 25.30 & 22.91 & 53.81 & 45.00 & 22.78 \\
\hline \multicolumn{12}{|c|}{ ANA $x$ ERE } \\
\hline Average & 58.32 & 52.09 & 3.10 & 32.60 & 1.06 & - & 6.58 & 4.67 & 6.01 & 6.39 & 0.91 \\
\hline Minimum & 42.00 & 40.00 & 2.25 & 21.25 & 0.75 & - & 4.40 & 3.75 & 2.05 & 4.25 & 0.47 \\
\hline Maximum & 80.00 & 70.50 & 4.25 & 46.75 & 1.35 & - & 11.15 & 5.35 & 8.40 & 9.25 & 0.75 \\
\hline $\mathrm{SD}$ & 15.09 & 11.88 & 0.80 & 7.56 & 0.18 & - & 2.22 & 0.68 & 2.25 & 1.54 & 0.35 \\
\hline CV $(\%)$ & 25.87 & 22.81 & 25.81 & 23.19 & 16.98 & - & 33.74 & 14.56 & 37.44 & 24.10 & 38.32 \\
\hline \multicolumn{12}{|c|}{ ERE x BRA1 } \\
\hline Average & 79.25 & 82.10 & 4.25 & 34.78 & 1.63 & - & 8.50 & 6.95 & 10.68 & 10.84 & 1.26 \\
\hline Minimum & 68.00 & 73.10 & 3.80 & 20.30 & 1.45 & - & 7.95 & 6.30 & 7.90 & 8.90 & 0.99 \\
\hline Maximum & 93.00 & 87.25 & 4.85 & 41.00 & 1.85 & - & 9.25 & 8.15 & 13.15 & 14.80 & 1.42 \\
\hline $\mathrm{SD}$ & 10.08 & 5.74 & 0.40 & 8.25 & 0.17 & - & 0.61 & 0.82 & 2.74 & 2.75 & 0.50 \\
\hline CV $(\%)$ & 12.72 & 6.99 & 9.41 & 23.72 & 10.43 & - & 7.18 & 11.80 & 25.66 & 25.37 & 39.79 \\
\hline \multicolumn{12}{|c|}{ BRA $x$ ERE } \\
\hline Average & 81.20 & 72.55 & 3.68 & 35.77 & 1.34 & - & 8.40 & 6.30 & 7.31 & 6.32 & 0.87 \\
\hline Minimum & 66.75 & 57.50 & 2.95 & 22.65 & 1.15 & - & 6.75 & 4.85 & 2.00 & 2.90 & 0.30 \\
\hline Maximum & 96.00 & 87.50 & 4.20 & 53.50 & 1.65 & - & 10.90 & 7.10 & 9.95 & 9.30 & 0.91 \\
\hline SD & 13.34 & 12.16 & 0.56 & 11.75 & 0.19 & - & 1.61 & 0.90 & 3.09 & 2.46 & 0.42 \\
\hline CV (\%) & 16.43 & 16.76 & 15.22 & 32.85 & 14.18 & - & 19.17 & 14.29 & 42.27 & 38.92 & 48.26 \\
\hline \multicolumn{12}{|c|}{ ERE x BRA2 } \\
\hline Average & 74.88 & 55.80 & 3.68 & 30.09 & 1.44 & - & 7.95 & 5.78 & 8.38 & 7.24 & 1.05 \\
\hline Minimum & 55.00 & 42.70 & 2.75 & 21.00 & 1.25 & - & 5.10 & 4.85 & 2.00 & 2.90 & 0.39 \\
\hline Maximum & 90.50 & 77.75 & 4.35 & 41.00 & 1.65 & - & 10.90 & 6.85 & 13.65 & 14.50 & 1.25 \\
\hline $\mathrm{SD}$ & 17.44 & 15.22 & 0.67 & 8.28 & 0.22 & - & 2.40 & 0.98 & 4.80 & 5.05 & 0.70 \\
\hline CV $(\%)$ & 23.29 & 27.28 & 18.21 & 27.52 & 15.28 & - & 30.19 & 16.96 & 57.28 & 69.75 & 66.41 \\
\hline \multicolumn{12}{|c|}{ ERE x ANA } \\
\hline Average & 52.25 & 49.63 & 2.38 & 26.00 & 1.10 & - & 5.08 & 3.98 & 5.03 & 4.88 & 0.99 \\
\hline Minimum & 39.50 & 38.50 & 1.50 & 23.25 & 0.85 & - & 2.85 & 2.75 & 1.70 & 2.15 & 0.60 \\
\hline Maximum & 65.00 & 60.75 & 3.25 & 28.75 & 1.35 & - & 7.30 & 5.20 & 8.35 & 7.60 & 1.14 \\
\hline $\mathrm{SD}$ & 18.03 & 15.73 & 1.24 & 3.89 & 0.35 & - & 3.15 & 1.73 & 4.70 & 3.85 & 0.38 \\
\hline CV (\%) & 34.51 & 31.69 & 52.10 & 14.96 & 31.82 & - & 62.01 & 43.47 & 93.44 & 78.89 & 38.38 \\
\hline
\end{tabular}


permutations) showed a good fit between the graphical representation of the distances and the original distance matrix (Rohlf \& Fisher 1968).

Multivariate analysis of the 26 hybrids allowed the formation of 7 groups (Figure 1) by the UPGMA based on the mean Euclidian distance between the hybrids, using a genetic dissimilarity cutoff $(D d g)$ of 0.28. Based on the particularities of each hybrid, it was possible to include them in use categories. The distribution was highly variable and some showed aptitude for inclusion in more than one category.

Group G1 is composed of the ORN-02, ORN-16 and ORN-17 hybrids, coming from two crosses: COM x COM and ERE x BRA2 (Figure 1). These three hybrids are suitable for two use categories: landscaping and potted plants. The landscaping use involves great plasticity, and all the hybrids fit in this category. The use of a particular hybrid for this purpose depends more on the skill of the landscaper than on the particular traits of the plant variety. The only situation where a variety would not be suitable for landscaping is when the fruit is hidden by leaves, as described in the methodology section. In turn, potted plants demand specific characteristics, mainly small size, short stems and preferably open or decumbent habit.

Group G2 contains the ORN-26, ORN-18 and ORN-19 hybrids, of which the first two are suitable for landscaping, cut flowers and foliage, and the last two for landscaping and foliage. The hybrids of this group come from two distinct crosses, although both share a common parent: A. comosus var. erectifolius. The inclusion in the foliage category was mainly due to the large length and width of leaves, greater than $80 \mathrm{~cm}$ and $4 \mathrm{~cm}$, respectively. This was expected based on the traits of the parents. A. comosus var. erectifolius has long and narrow leaves without thorns, while $A$. comosus var. bracteatus has long and broad leaves with thorns (Souza et al. 2012a). The plants in this group presented similar characteristics,

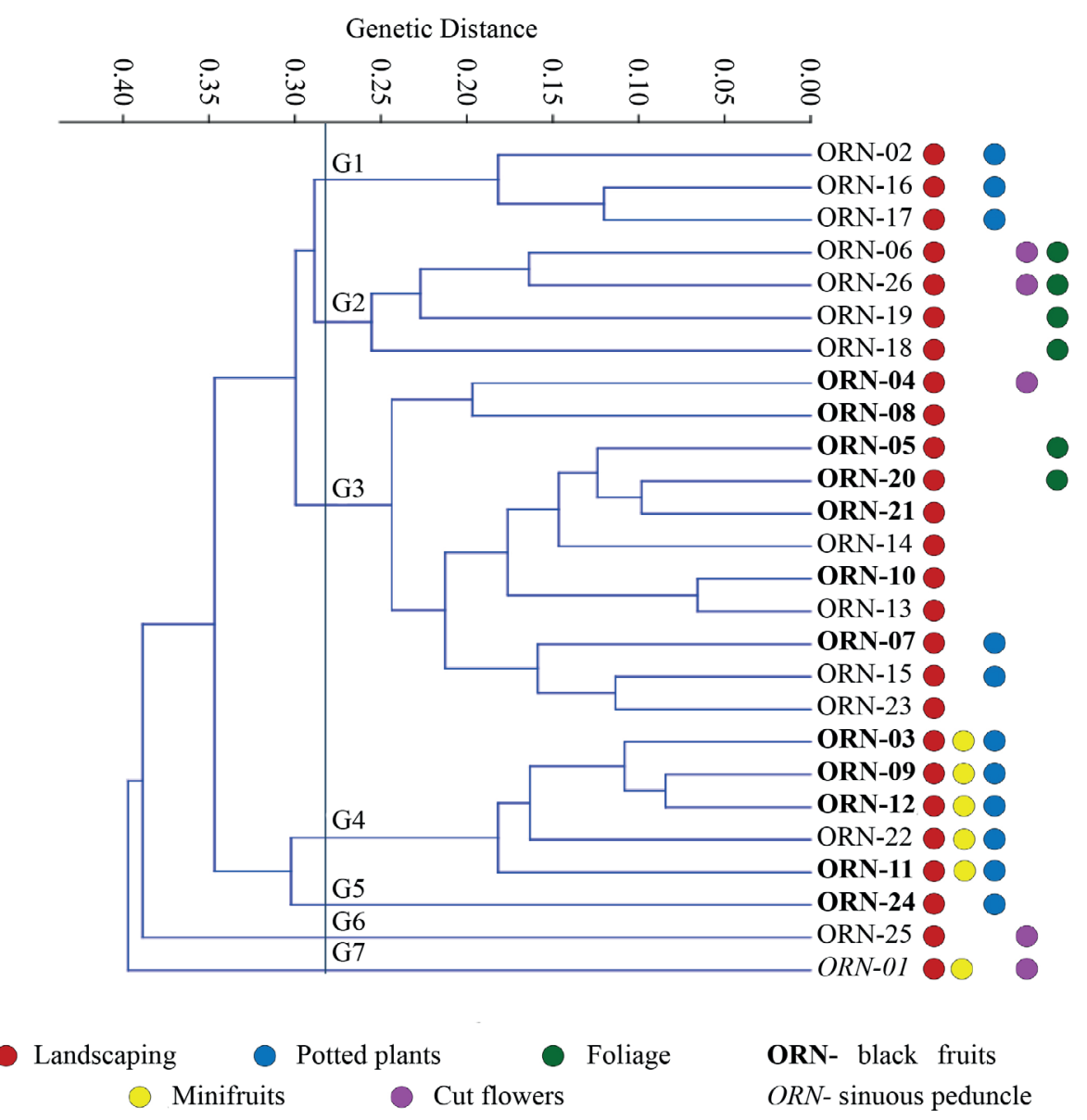

Figure 1. Dendrogram of the genetic dissimilarities among 26 pineapple hybrids from different parents, achieved by the UPGMA method based on the Gower algorithm, from 23 qualitative and quantitative descriptors. 
regarding erect habit, conical to cylindrical fruit shape, pink color and moderately acute crown apex shape.

Groups G3 and G4 contain 16 hybrids resulting from five crosses (Figure 1). These groups contain the majority of the genotypes bearing black fruits $(69 \%)$ selected in this study (Figure 2a-d). The denomination black pineapple used here is due to the high concentration of anthocyanin in the syncarp. Anthocyanin confers fruits a dark appearance, even when the bracts of the fruitlet are reddish. This unique fruit color trait is present in one of the parents, BGA 526 (A. comosus var. ananassoides), and in the two accessions of $A$. comosus var. erectifolius used in all the crosses.

The black color is rare in nature and also in the flower growing segment, where novelty typically brings added value due to rarity and exoticism. Other examples are black tulip and rose (Carlson 1980), iris (Al-Khassawneh et al. 2006) and lisianthus (Markham et al. 2004). In the case of pineapple, only the syncarp approaches a black

Table 2. Quantitative and qualitative plant traits of 26 ornamental pineapple hybrids grouped by progenies.

\begin{tabular}{|c|c|c|c|c|c|c|c|c|c|c|}
\hline Hybrid & PLH & LLS & LWS & PEL & PED & HAB & LVA & DLV & ANT & PES \\
\hline \multicolumn{11}{|c|}{ ANA x (ERE x ANA) } \\
\hline ORN-01 & 71.00 & 69.00 & 2.70 & 79.00 & 1.20 & $\mathrm{DEC}$ & ABS & WVA & ABS & SIN \\
\hline \multicolumn{11}{|c|}{$\mathrm{COM} \times \mathrm{COM}$} \\
\hline ORN-02 & 55.00 & 47.00 & 2.25 & 32.25 & 1.25 & OPE & PRE & $\mathrm{CEN}$ & ABS & STR \\
\hline \multicolumn{11}{|c|}{ ANA $x$ ERE } \\
\hline ORN-03 & 47.00 & 46.75 & 3.00 & 32.00 & 1.10 & OPE & ABS & WVA & PRE & STR \\
\hline ORN-04 & 77.50 & 63.75 & 3.90 & 46.75 & 1.20 & OPE & ABS & CEN & PRE & STR \\
\hline ORN-07 & 48.35 & 42.45 & 2.30 & 34.60 & 1.10 & OPE & PRE & WVA & PRE & STR \\
\hline ORN-08 & 70.24 & 63.75 & 3.85 & 37.75 & 1.10 & OPE & PRE & WVA & PRE & STR \\
\hline ORN-09 & 42.00 & 40.00 & 2.25 & 26.50 & 0.95 & OPE & ABS & WVA & PRE & STR \\
\hline ORN-10 & 80.00 & 70.50 & 4.25 & 32.00 & 1.35 & OPE & ABS & WVA & PRE & STR \\
\hline ORN-11 & 52.50 & 44.00 & 2.40 & 29.70 & 0.75 & OPE & ABS & WVA & PRE & STR \\
\hline ORN-12 & 49.00 & 45.50 & 2.85 & 21.50 & 0.95 & OPE & ABS & WVA & PRE & STR \\
\hline \multicolumn{11}{|c|}{ ERE $x$ BRA1 } \\
\hline ORN-05 & 73.50 & 87.25 & 3.80 & 36.75 & 1.55 & OPE & ABS & WVA & PRE & STR \\
\hline ORN-18 & 93.00 & 86.15 & 4.30 & 20.30 & 1.45 & OPE & ABS & WVA & ABS & STR \\
\hline ORN-20 & 68.00 & 80.00 & 4.30 & 37.60 & 1.65 & OPE & ABS & WVA & $\mathrm{ABS}$ & STR \\
\hline ORN-21 & 75.75 & 73.10 & 4.85 & 38.25 & 1.85 & ERE & ABS & WVA & ABS & STR \\
\hline ORN-26 & 86.00 & 84.00 & 4.00 & 41.00 & 1.30 & ERE & PRE & MAR & ABS & STR \\
\hline \multicolumn{11}{|c|}{ BRA x ERE } \\
\hline ORN-06 & 93.25 & 82.25 & 4.15 & 53.50 & 1.35 & ERE & PRE & WVA & ABS & STR \\
\hline ORN-13 & 79.00 & 68.50 & 3.85 & 35.75 & 1.35 & OPE & ABS & WVA & PRE & STR \\
\hline ORN-14 & 71.00 & 57.50 & 2.95 & 38.75 & 1.15 & OPE & ABS & WVA & PRE & STR \\
\hline ORN-15 & 65.75 & 67.00 & 3.25 & 22.65 & 1.20 & OPE & ABS & WVA & PRE & STR \\
\hline ORN-19 & 96.00 & 87.50 & 4.20 & 28.20 & 1.65 & ERE & ABS & WVA & ABS & STR \\
\hline \multicolumn{11}{|c|}{ ERE x BRA2 } \\
\hline ORN-16 & 65.50 & 52.50 & 3.75 & 30.25 & 1.25 & ERE & PRE & MAR & $\mathrm{ABS}$ & STR \\
\hline ORN-17 & 55.00 & 50.25 & 2.75 & 21.00 & 1.25 & OPE & PRE & $\mathrm{CEN}$ & ABS & STR \\
\hline ORN-23 & 90.50 & 77.75 & 3.85 & 28.10 & 1.65 & OPE & PRE & WVA & PRE & STR \\
\hline ORN-25 & 88.50 & 42.70 & 4.35 & 41.00 & 1.60 & OPE & PRE & WVA & PRE & STR \\
\hline \multicolumn{11}{|c|}{ ERE x ANA } \\
\hline ORN-22 & 39.50 & 38.50 & 1.50 & 28.75 & 0.85 & OPE & ABS & WVA & PRE & STR \\
\hline ORN-24 & 65.00 & 60.75 & 3.25 & 23.25 & 1.35 & DEC & ABS & WVA & PRE & STR \\
\hline
\end{tabular}

PLH: plant height (cm); LLD: leaf "D" length (cm); LWD: leaf "D" width (cm); PEL: peduncle length after closure of the last flower (cm); PED: peduncle diameter after closure of the last flower $(\mathrm{cm})$; HAB: plant habit; LVA: presence/absence of leaf variegation; DLV: distribution of leaf variegation; ANT: presence/absence of anthocyanin in leaves; PES: peduncle shape; ERE: erect; OPE: open; DEC: decumbent; ABS: absent; PRE: present; WVA: without variegation; CEN: central; MAR: marginal; SIN: sinuous; STR: straight. 
color, which is accompanied by reddish bracts, giving the plant a singular appearance (Figure $2 c-d)$.

Group G4 also contains hybrids suitable for landscaping, mini fruits and potted plants, sharing as common parent accessions of $A$. comosus var. ananassoides, which has small size and fruits. The ORN-24, ORN-25 and ORN-01 hybrids formed three distinct groups (G5, G6 and G7, respectively), originating from different crosses (Tables 2 and 3). The ORN-24 hybrid was classified as suitable for landscaping and potted plants, while ORN-25 is suitable for landscaping and cut flowers.
The ORN-01 hybrid was selected for cut flowers, mini fruits and landscaping, presenting a peduncle length of $79 \mathrm{~cm}$ and diameter of $1.2 \mathrm{~cm}$. These measures are outside the normal pattern for the stem length preferred in the current market. The shape of the peduncle was sinuous, with one to three curves, making the plants a novelty for the floriculture segment (Figure 2e). This trait of long and sinuous peduncle is related to the parent (A. comosus var. ananassoides).

Overall, the results found in this study increase the range of traits for tropical floriculture, with potential as varieties with new features for the flower and ornamental plant market.

Table 3. Quantitative and qualitative fruit traits of 26 ornamental pineapple hybrids grouped by progenies.

\begin{tabular}{|c|c|c|c|c|c|c|c|c|c|c|c|c|}
\hline Hybrid & SYL & SYD & CRL & CRD & CSR & SYS & SYC & BAS & $\mathrm{BSC}$ & $\mathrm{BFO}$ & $\mathrm{NCC}$ & CAS \\
\hline \multicolumn{13}{|c|}{ ANA x (ERE x ANA) } \\
\hline ORN-01 & 7.10 & 5.00 & 4.60 & 2.80 & 0.65 & $\mathrm{COC}$ & PIN & $\mathrm{ACU}$ & PAR & ABS & CRS & MAC \\
\hline \multicolumn{13}{|c|}{$\mathrm{COM} \times \mathrm{COM}$} \\
\hline ORN-02 & 5.85 & 5.85 & 5.65 & 4.40 & 0.97 & GLO & PIN & $\mathrm{ACU}$ & PAR & $\mathrm{ABS}$ & CRS & MAC \\
\hline \multicolumn{13}{|c|}{ ANA $x$ ERE } \\
\hline ORN-03 & 5.10 & 4.45 & 4.45 & 4.75 & 0.87 & CYL & BLK & $\mathrm{ACU}$ & PAR & ABS & CR1 & MAC \\
\hline ORN-04 & 11.15 & 5.15 & 7.75 & 6.55 & 0.70 & $\mathrm{CON}$ & BLK & $\mathrm{ACU}$ & PAR & ABS & CR2 & MAC \\
\hline ORN-07 & 6.85 & 5.35 & 8.00 & 9.25 & 1.17 & $\mathrm{COC}$ & BLK & $\mathrm{ACU}$ & TOT & ABS & $\mathrm{CR} 2$ & MAC \\
\hline ORN-08 & 7.10 & 5.30 & 5.70 & 6.80 & 0.80 & $\mathrm{COC}$ & BLK & $\mathrm{ACU}$ & PAR & ABS & CR1 & MAC \\
\hline ORN-09 & 4.40 & 3.95 & 7.35 & 7.15 & 1.67 & CYL & BLK & $\mathrm{ACU}$ & PAR & ABS & $\mathrm{CR} 2$ & MAC \\
\hline ORN-10 & 8.20 & 5.30 & 8.40 & 6.60 & 1.02 & $\mathrm{CON}$ & BLK & $\mathrm{ACU}$ & TOT & ABS & CR1 & MAC \\
\hline ORN-11 & 4.65 & 4.10 & 4.35 & 4.25 & 0.94 & $\mathrm{CON}$ & BLK & ACU & PAR & ABS & CR1 & MAC \\
\hline ORN-12 & 5.20 & 3.75 & 2.05 & 5.80 & 0.39 & ELL & BLK & $\mathrm{ACU}$ & PAR & ABS & CR2 & MAC \\
\hline \multicolumn{13}{|c|}{ ERE $x$ BRA1 } \\
\hline ORN-05 & 8.75 & 8.15 & 12.90 & 14.80 & 1.47 & ELL & BLK & $\mathrm{ACU}$ & TOT & ABS & CR2 & MAC \\
\hline ORN-18 & 8.05 & 6.75 & 8.75 & 9.05 & 1.09 & $\mathrm{CON}$ & PIN & $\mathrm{ACU}$ & TOT & ABS & CR2 & TAP \\
\hline ORN-20 & 9.25 & 6.30 & 7.90 & 8.90 & 0.85 & CYL & BLK & $\mathrm{ACU}$ & TOT & ABS & CR2 & MAC \\
\hline ORN-21 & 7.95 & 6.60 & 13.15 & 10.60 & 1.65 & $\mathrm{COC}$ & BLK & $\mathrm{ACU}$ & TOT & ABS & $\mathrm{CR} 2$ & MAC \\
\hline ORN-26 & 6.20 & 5.50 & 5.70 & 4.90 & 0.92 & $\mathrm{COC}$ & PIN & $\mathrm{ACU}$ & PAR & ABS & $\mathrm{CR} 2$ & MAC \\
\hline \multicolumn{13}{|c|}{ BRA x ERE } \\
\hline ORN-06 & 8.80 & 7.10 & 7.85 & 5.25 & 0.89 & $\mathrm{COC}$ & PIN & $\mathrm{ACU}$ & TOT & ABS & CR2 & MAC \\
\hline ORN-13 & 8.25 & 6.80 & 9.95 & 9.30 & 1.21 & $\mathrm{COC}$ & PIN & $\mathrm{ACU}$ & TOT & ABS & CR1 & MAC \\
\hline ORN-14 & 6.75 & 6.70 & 8.80 & 7.90 & 1.30 & CYL & PIN & $\mathrm{ACU}$ & TOT & ABS & CR2 & MAC \\
\hline ORN-15 & 7.30 & 6.05 & 7.95 & 6.25 & 1.09 & CYL & PIN & $\mathrm{ACU}$ & TOT & ABS & $\mathrm{CR} 2$ & MAC \\
\hline ORN-19 & 10.90 & 4.85 & 2.00 & 2.90 & 0.18 & $\mathrm{COC}$ & PIN & $\mathrm{ACU}$ & TOT & ABS & $\mathrm{CR} 2$ & MAC \\
\hline \multicolumn{13}{|c|}{ ERE x BRA2 } \\
\hline ORN-16 & 5.10 & 5.05 & 8.85 & 6.35 & 1.74 & CYL & PIN & $\mathrm{ACU}$ & TOT & PRE & CR2 & MAC \\
\hline ORN-17 & 10.90 & 4.85 & 2.00 & 2.90 & 0.18 & $\mathrm{COC}$ & PIN & $\mathrm{ACU}$ & TOT & PRE & $\mathrm{CR} 2$ & MAC \\
\hline ORN-23 & 8.40 & 6.35 & 9.00 & 5.20 & 1.07 & $\mathrm{COC}$ & PIN & $\mathrm{ACU}$ & TOT & ABS & CR2 & MAC \\
\hline ORN-25 & 7.40 & 6.85 & 13.65 & 14.50 & 1.84 & CYL & PIN & $\mathrm{ACU}$ & TOT & ABS & CR1 & MAC \\
\hline \multicolumn{13}{|c|}{ ERE x ANA } \\
\hline ORN-22 & 2.85 & 2.75 & 1.70 & 2.15 & 0.60 & CYL & PIN & $\mathrm{ACU}$ & PAR & ABS & CR2 & MAC \\
\hline ORN-24 & 7.30 & 5.20 & 8.35 & 7.60 & 1.14 & CYL & BLK & $\mathrm{ACU}$ & PAR & PRE & CR1 & MAC \\
\hline
\end{tabular}

ORN in boldface denotes plants that produce black fruits; SYL: syncarp length after closure of the last flower (cm); SYD: syncarp diameter after closure of the last flower (cm); CRL: crown length after closure of the last flower (cm); CRD: crown diameter after closure of the last flower (cm); CSR: crown/syncarp ratio; SYS: syncarp shape; SYC: syncarp color; BAS: bract apex shape; BSC: bract shape at crown base; BFO: overlap of bracts in relation to fruitlet; NCC: number of crown colors; CAS: crown apex shape; COC: conical/cylindrical; GLO: globular; CYL: cylindrical; CON: conical; ELL: elliptical; BLK: black; PIN: pink; ACU: acute; PAR: partial; TOT: total; ABS: absent; PRE: present; CR1: color; CR2: colors; MAC: moderately acute; TAP: tapering. 

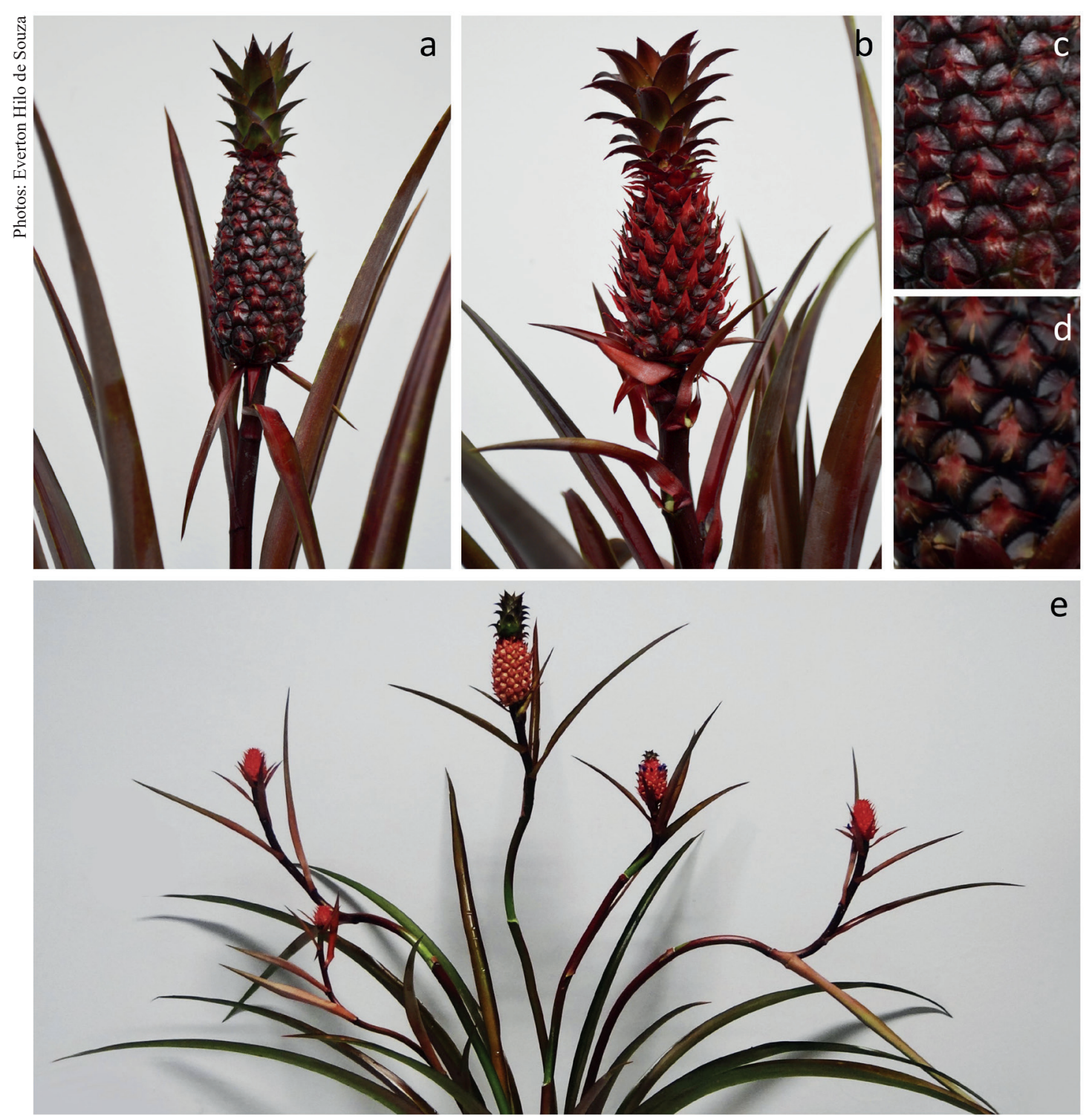

Figure 2. Ornamental pineapple hybrids selected with black fruits (a, c), reddish bracts (b-d) and sinuous stems (e), developed by the genetic improvement program of the Embrapa Mandioca e Fruticultura. a and c: ORN-04; b and d: ORN-21; e: ORN-01.

\section{CONCLUSIONS}

1. Among the 26 hybrids evaluated, 5 were selected for cut flowers, 11 for potted plants, 6 for mini fruits and 6 for foliage;

2. Twelve hybrids produced black flowers;

3. One hybrid (ORN-01) was selected for having a sinuous stem and being suitable for producing cut flowers;

4. The hybrid with sinuous stem and those bearing black fruits are innovations that may be successful either in the cut flowers market or as ornamental plants.

\section{ACKNOWLEDGMENTS}

We acknowledge the financial support from the Conselho Nacional de Desenvolvimento Científico e Tecnológico (CNPq) and Coordenação de Aperfeiçoamento de Pessoal de Nível Superior (Capes - Embrapa n ${ }^{\circ}$ 15/2014 and PROCAD-2013).

\section{REFERENCES}

AL-KHASSAWNEH, N. M.; KARAM, N. S.; SHIBLI, R. A. Growth and flowering of black iris (Iris nigricans Dinsm.) following treatment with plant growth 
regulators. Scientia Horticulturae, v. 107, n. 2, p. 187193, 2006.

BRASIL. Ato ${ }^{\circ} 2$, de 2 de janeiro de 2013. Diário Oficial da República Federativa do Brasil. Brasília, DF, 03 jan. 2013. Seção1, p. 4.

CARLSON, P. S. Blue roses and black tulips: is the new plant genetics only ornamental? In: STAPLES, R. C.; KUHR, R. J. (Eds.). Linking research to crop production. Boston: Springer, 1980. p. 63-77.

COSTA JUNIOR, D. S. et al. Clonal evaluation of new ornamental pineapple hybrids to use as cut flowers. Acta Scientiarum: Agronomy, v. 38, n. 4, p. 475-483, 2016.

CUNHA, G. A. P.; CABRAL, J. R. S.; SOUZA, L. F. $O$ abacaxizeiro: cultivo, agroindústria e economia. Brasília, DF: Embrapa Comunicação e Transferência de Tecnologia, 1999.

DEL BOSCO, S. F. The use for ornamental purposes of an ancient Citrus genotype. Acta Horticulturae, v. 589, n. 1, p. 65-67, 2003.

GOWER, J. C. A general coefficient of similarity and some of its properties. Biometrics, v. 27, n. 4, p. 857-874, 1971.

HÄKKINEN, M.; SHARROCK, S. Diversity in the genus Musa: focus on Rhodochlamys. In: INSTITUTE FOR THE IMPROVEMENT OF BANANAAND PLANTAIN (INIBAP). Annual report. Montpellier: INIBAP, 2001. p. 16-23.

LIMA, O. S. et al. Seleção de híbridos negros e hastes sinuosas de abacaxizeiros. In: JORNADA CIENTÍFICA DA EMBRAPA MANDIOCA E FRUTICULTURA, 9., 2015, Cruz das Almas. Anais... Cruz das Almas: Embrapa Mandioca e Fruticultura, 2015. p. 154-154.

MARKHAM, K. R. et al. Black flower coloration in wild Lisianthius nigrescens: its chemistry and ecological consequences. Zeitschrift für Naturforschung C, v. 59, n. 9-10, p. 625-630, 2004.

ROHLF, F. J.; FISHER, D. R. Tests for hierarchical structure in random data sets. Systematic Biology, v. 17, n. 4, p. 407-412, 1968.

SANEWSKI, G. M. Breeding Ananas for the cut-flower and garden markets. Acta Horticulturae, v. 822, n. 1, p. 71-78, 2009.

SANTOS, A. R. A. et al. Genetic variation of Citrus and related genera with ornamental potential. Euphytica, v. 205 , n. 2, p. 503-520, 2015.
SANTOS, A. R. A. et al. Selection of CTV-tolerant citrus hybrids for ornamental use. Fruits, v. 71, n. 6, p. 389-398, 2016.

SANTOS-SEREJO, J. A. et al. Caracterização morfológica de bananeiras ornamentais. Magistra, v. 19, n. 4, p. 326332, 2007.

SANTOS-SEREJO, J. A. et al. Selection and use recommendation in hybrids of ornamental banana. Crop Science, v. 52, n. 2, p. 560-567, 2012.

SAS INSTITUTE INC. SAS/STAT 9.2 user's guide. Cary: SAS Institute Inc., 2010.

SERVIÇO BRASILEIRO DE APOIO ÀS MICRO E PEQUENAS EMPRESAS (Sebrae). Flores e plantas ornamentais do Brasil. 2015. Available at: <http:// www.hortica.com.br/artigos/2015/FPO BR Estudos Mercadologicos_2015_Vol1.pdf $>$. Access on: 14 Nov., 2016.

SOKAL, R. R.; ROHLF, F. J. The comparison of dendrograms by objective methods. Taxon, v. 11, n. 2, p. 33-40, 1962.

SOUZA, E. H. et al. Genetic variability of banana with ornamental potential. Euphytica, v. 184, n. 3, p. 355-367, $2012 b$.

SOUZA, E. H. et al. Genetic variation of the Ananas genus with ornamental potential. Genetic Resources and Crop Evolution, v. 59, n. 7, p. 1357-1376, 2012a.

SOUZA, E. H. et al. Seletion and use recommendation in hybrids of ornamental pineapple. Revista Ciências Agronômicas, v. 45, n. 2, p. 409-416, 2014.

SOUZA, E. H.; LIMA, O. S.; SOUZA, F. V. Hastes sinuosas de abacaxi ornamental como inovação para o mercado de flor de corte. In: CONGRESSO BRASILEIRO DE FLORICULTURA E PLANTAS ORNAMENTAIS, 20.; CONGRESSO BRASILEIRO DE CULTURA DE TECIDOS DE PLANTAS, 7., 2015, Piracicaba. Anais.... Piracicaba: Esalq, 2015. p. 432-432.

SOUZA, F. V. D. et al. Evaluation of F1 hybrids between Ananas comosus var. ananassoides and Ananas comosus var. erectifolius. Acta Horticulturae, v. 822, n. 1, p. 7984, 2009.

STOKER, T. New ornamental banana. Trends in Plant Science, v. 6, n. 9, p. 404, 2004. 